\title{
Дары-подношения священным местам в Эстонии и Финляндии: сравнительный анализ
}

\author{
Тынно Йонукс \\ Отделение фольклористики, Эстонский литературный музей, \\ Эстония \\ tonno@folklore.ee
}

\section{Тийна Айкас}

археология, гуманитарный фракультет, Университет Оулу, Финляндия

tiina.aikas@oulu.fi

\begin{abstract}
Аннотация: Данная статья основана на полевых археологических исследованиях, которые проводились в священных местах Эстонии и Финляндии. Мы изучаем вариативность современных наборов подношений в этих странах и интерпретируем их на основе известных традиций современного язычества. Современные подношения несут на себе след творческого переосмысления прошлого и испытывают влияние международных традиций. Также подчёркивается, что люди, посещающие священные места, - это более широкая категория, чем члены языческих сообществ, однако исследователи их часто обходят вниманием. Отношение широких масс к этим местам становится особенно очевидным в процессе изучения материальной культуры и комплексного анализа всех даров.
\end{abstract}

Ключевые слова: исследование современности, язычество, подношения, исследования материальной культуры 


\section{Введение}

В последние десятилетия современное языческое движение стремительно расширяется. Титус Хьельм $(2016,360)$ утверждает, что хотя в целом признание и исследование разных форм современного язычества возрастает, «существует вариативность в интенсивности возникновения современного язычества в разных социальных контекстах». Современное язычество состоит из большого количества разных направлений, начиная от более универсальных (викки, друиды и неошаманисты) и заканчивая местными этническими формами язычества и реконструктивизма (см. Sjöblom 2000: 237). В отличие от универсальных фрорм язычества, этнические направления язычества в Восточной Европе берут за основу национальную идею, традиционный фрольклор и обряды, а также ограниченную территорию и в целом ассоциируют свои верования с дохристианскими традициями определённого народа (см., например, Ivakhiv 2005). Из-за стремления этих сообществ подчеркнуть свои связи с местной историей и народом, данные традиции также называются «нативными». Такие группы обычно уважительно относятся к природе и местным сакральным местам. Соответственно, рост современного язычества также повлёк за собой значительное увеличение количества подношений в различных местах. Когда эти дары оставляют в природных местах, они напрямую или косвенно ассоциируются со старыми и традиционными обрядами почитания природы, а подношения символизируют пожелание, молитву или просто отмечают посещение места. В различных местах следствием этого стали нагромождения лоскутов и монет, но иногда попадаются и более личные и уникальные предметы.

В данном исследовании мы анализируем, какие артефакты оставляют в дар в священных местах. Священные места в данном исследовании - это природные объекты, где оставляют дары и подношения. Несмотря на то, что обычно для определения священных мест используют также дополнительные критерии, такие как время, аутентичность или цели посещений (например, Kaasik 2007; Muinsuskaitseamet: https:/www. muinsuskaitseamet.ee/et/ajaloolised-ja-looduslikud-puhapaigad), в данном случае они не важны. Тем не менее, выбирая объекты для детального изучения, мы исключили популярные 
туристические места и объекты с «замками любви»; таким образом, нашей целью является всё же изучение религиозного феномена. Руководствуясь методологией археологии, мы основывались прежде всего на материальных источниках и использовали данные интервью лишь для интерпретации общей информации о священных местах Эстонии и Финляндии. Эти две соседствующие страны представляют собой интересный пример переплетения сходств и различий, позволяя сделать выводы с более широкой интерпретацией. Обе страны принадлежат к одной языковой семье, которая также сближает их с более восточными финно-угорскими народами. Такое древнее происхождение стало причиной для часто используемого национального нарратива об общей истории, мировоззрении и верованиях, разделяемых многими финно-угорскими народами, но в первую очередь фриннами и эстонцами. Тем не менее, в силу исторических причин завоевания и образования государства в XIII в., Финляндия более ориентирована на Скандинавию, в то время как Эстония - на континентальную Европу. Национальный нарратив также активно используется языческими сообществами обеих стран, утверждающими, что они имеют взаимосвязанные характеристики. Тем не менее, положение языческих сообществ в этих странах значительно отличается - языческая группа maausk (землеверие) и организация Maavalla Koda (Дом Земли) в Эстонии очень влиятельны и формируют отношение к священным местам как среди других языческих групп, так и среди широких масс населения, в то время как в Финляндии это движение всё ещё остаётся довольно маргинальным с небольшой организацией, и борющимся за легитимизацию (Rountree 2014; Västrik 2015; Hjelm 2016, 360; Jonuks в печати). Более общая цель данной статьи - провести обзор современных подношений в священных местах и изучить разные цели посещения и подношения даров. Например, кто их посетители и как национальный нарратив, часто находящийся в центре языческого дискурса, или их личные цели отражают современное использование священных мест? 


\section{Язычество в Эстонии и Финляндии}

Достаточно сложно установить, когда и как в Эстонии появились современные языческие традиции. Следуя общеевропейским традициям начала XX в., неоязыческое движение появилось также в Эстонии. В честь единственного дохристианского бога Тарапиты (Таары), известного по «Хронике» Генриха Ливонского начала XIII в., движение было названо Taarausulised (Таараверы) (более подробно см. у Vakker 2012). Это сообщество перестало действовать к 1940 г., когда советская оккупационная власть запретила большинство религиозных организаций в Эстонии и лидеры организации (главным образом, офицеры и националистически настроенные члены) были депортированы в Сибирь. Таким образом, организация была закрыта в 1940 г., но тем не менее, отдельные её члены остались в Эстонии и продолжали тайно заниматься своей деятельностью. С точки зрения этического подхода, участие в народном языческом движении наверняка рассматривалось как часть противостояния во время советского периода. В 1960-х представители нового поколения, некоторые из которых были прямыми наследниками группы Taarausulised, сформулировали новую концепцию: maausk (землеверие), которая приобрела значение религии этой земли. В противовес своим предшественникам Taarausulised, новое движение, названное Maausulised (землеверы), утверждало, что оно не является неоязыческой религией, так как оно придерживается эстонской фольклорной традиции и, соответственно, отражает коренное мировоззрение эстонцев с незапамятных времён. До конца 1980-х гг., движение было практически незаметным и действовало тайно. Конец 1980-х гг., период становления независимости Эстонии, ознаменовался появлением большого количества разнообразных религиозных движений в ранее официально атеистическом обществе (Rohtmets \& Ringvee 2013), и группа современных язычников также стала активна. Их утверждения о следовании исконным эстонским традициям уместно вписались в более широкий контекст значительной популярности национальной идеи, изучения и пропаганды эстонской культуры. Хотя в 1990-е гг. деятельность группы была ограниченной, но она стала привлекать к себе всенародное внимание с ранних 2000-х после 
первой кампании по охране священного места. C тех пор было проведено ещё несколько общественных кампаний для защиты священных объектов, что предоставило движению отличную площадку для популяризации своих идей (более подробно см. Västrik 2015, Jonuks и др. в печати).

Оставляя в стороне споры об истории и научный подход к аутентичности движения Maausulised, важно отметить, что эта группа стала наиболее влиятельной не только среди других современных языческих движений, но также в вопросе формирования современной эстонской идентичности. Говоря словами Ринго Рингвее, у этого сообщества был очень успешный брендинг (Ringvee 2017, 64f). Подчёркивая уникальность эстонской культуры, её значительный возраст и способность сохранить местные особенности, которые давно были забыты в остальных частях Европы, движение подпитывало гордостью национальную идентичность, столь значимую для такой небольшой нации. Косвенно такой подход язычников поддерживают также эстонские писатели, которые также связывают уникальность эстонцев с их близкими отношениями с природой (например, известная трилогия-бестселлер Вальдура Микиты 2008, 2013, 2015). Вследствие этого, взгляды современного языческого сообщества также разделяют люди, которые не принадлежат к этой группе, но считают данные взгляды характерными для эстонцев. Хорошим примером этого является тот фракт, что даже некоторые священники эстонской лютеранской церкви придерживаются подобного подхода и активно защищают священные рощи, что будет подробнее описано ниже.

Maausulised позиционируют свой подход так, что значительная часть эстонцев рассматривает их деятельность как защиту культурного наследия, а не как религиозное движение. Это объясняет, почему их обычаи распространены так широко и проводятся по всей стране, часто с пояснением, что «это обычаи наших предков». В их сообществе представлены различные взгляды, от более радикальных до более толерантных к христианству и модернизации. Также разнятся и идеологические и религиозные подоплёки обычаев оставлять подношения в священных местах. Не только для членов сообщества maausulised, но и для остальных людей, принесение подношений, очевидно, является одним из наиболее заметных и эффрективных способов выразить поддержку языческой традиции в Эстонии и, продолжая нар- 
ратив, заложенный этим сообществом, также выразить свою национальную идентичность. Вероятно, это и есть причины того, почему языческое сообщество заняло такое влиятельное положение в эстонском обществе, что даже за границей Эстонию рекламируют как страну, следующую «неоязыческим заветам любви к природе» (The Economist 6.07.2017). И именно поэтому в священных местах в Эстонии можно обнаружить подношения весьма разнообразного происхождения.

В Финляндии с ранних 2000-х гг. постоянно растёт число людей, идентифицирующих себя с язычниками, и присутствие язычников в интернете (Hjelm 2016, 360). Уже в середине XIX в. к идеям о возрождении «древней духовной мудрости» привела публикация финского народного эпоса «Калевала» с историями про колдунов и магию (Hjelm 2016, 362). Но лишь позже, в конце 1970-х гг., современное язычество в Финляндии приняло упорядоченную форму, используя для своих практик элементы финского фольклора и стремясь воссоздать народную религию (Heino 1997; Hjelm 2006: 35-36).

Конец 1990-х гг. был отмечен возрождением интереса к современному язычеству, что привело к созданию новых ассоциаций. Lehto - Suomen luonnonuskontojen yhdistys ry (Роща - ассоциация финских природоверов; 'ry' обозначает зарегистрированную ассоциацию) - организация верующих в природу - была создана в 1998 г., а Pakanaverkko ry (Языческая сеть) - организация неоязычников и верующих в природу - была основана в 1999 г. Вторая волна началась десятилетием позже, когда Taivaannaula (Гвоздь небес) была создана в 2007 г., а Karhun kansa (Медвежьи люди) - организация последователей Финской Веры (suomenusko) - была создана в 2010 г. и зарегистрирована как официально признанное религиозное сообщество в 2013 г., став первой группой современных язычников, получившей этот статус. Некоторые последователи Финской Веры не идентифицируют себя как неоязычники. Ииро Арола (2011) использовал термин этно-язычники для обозначения тех из современных язычников, кто считает главным источником своей веры местную дохристианскую традицию. Например, Karhun kansa описывает свою фрункцию на своём сайте следующим образом: «Медвежьи люди представляют фринский этнический способ верования. Главные черты нашей религиозной жизни - 
сублимация природных практик, проведение традиционных календарных обрядов, семейные ценности и связь с предками, почитание различных сил, особенно Медведя, вера в душу [...]. Медвежьи люди дают членам своей организации свободу познания в рамках финского мировоззрения, корни которого восходят к праистории Урала. Это живая этническая религия, которая в полной мере осознала глубину своих корней». (http:// www.karhunkansa.fi/about_pages/view/14; курсив авторов)

Taivaannaula - это организация, содействующая развитию финских народных верований и традиций. Они не позиционируют себя как религиозное сообщество не считают себя таковым, но стремятся сохранить и поддерживать финскую традиционную культуру и народные верования. С этой целью в 2013 г. был начат проект по нанесению на карту финских hiisi-мест (священных мест), чтобы повысить осведомлённость об этих местах и более эфффективно защищать их. Они также работали вместе с эстонской Maavalla Koda, разделяют многие их идеи и подход к популяризации своих взглядов и верований, а также проводят совместные мероприятия. Поскольку их деятельность в священных местах даёт такой же материал, как и деятельность современных языческих групп, а их работа с hiisi внесла большой вклад в признание и использование священных мест, мы включаем их деятельность в данное исследование.

Современные языческие движения, особенно ключевые из них, обычно рассматриваются как главная группа посетителей священных мест. Следовательно, эти сообщества в большей или меньшей степени формируют общее понимание смыслов, обычаев и обрядов в священных местах. В стороне остаётся другая потенциальная аудитория, в частности альтернативные языческие сообщества и индивидуальные посетители. Очевидно, что организацию локализовать и изучить легче, чем отдельных индивидов, которые проводят собственные ритуалы и интерпретируют то, что видят. Но это также означает, что значительная часть посетителей священных мест часто игнорируется в исследованиях. Благодаря тому, что они также оставляют подношения, эта неструктурированная группа, включающая людей из разных слоёв общества, становится заметной при исследовании материальной культуры. 


\section{Современные подношения в Эстонии и Финляндии}

В этой статье мы представляем данные, документированные в процессе исследований, проведённых в эстонских и фринских священных местах, которые используются группой современных язычников или другими группами, почитающими духов в священных местах или выражающих свою национальную идентичность в природных священных местах. В Эстонии исследование

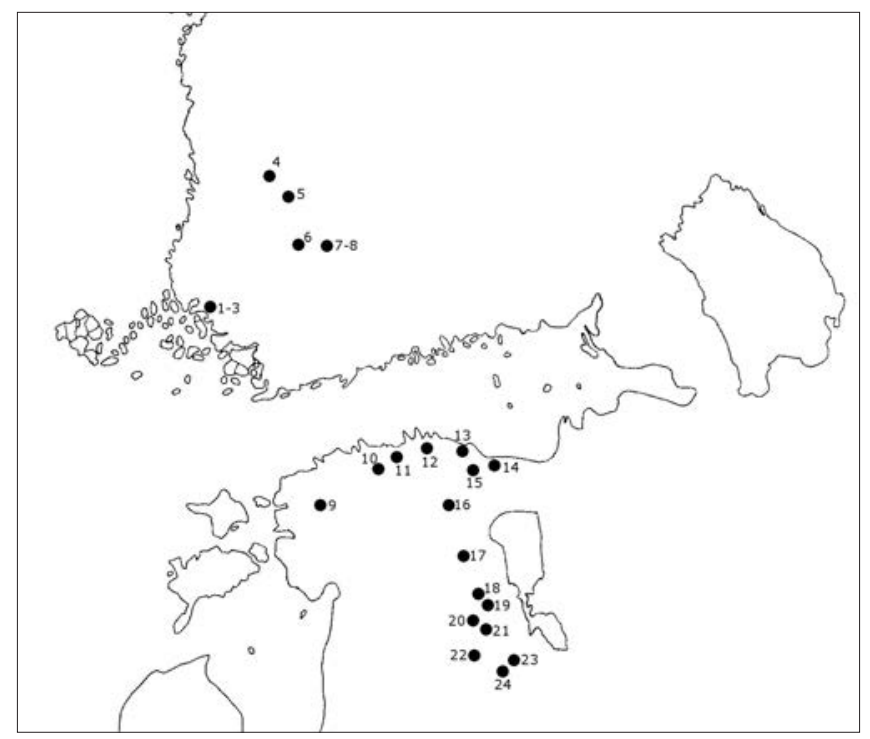

Рисунок 1. Карта священных мест в Финляндии и Эстонии, изученных в рамках этого исследования. Составитель карты Т. Йонукс. Список мест: 1. Турку, Мухкури, Ухриляхтәэнкату (Muhkuri, Uhrilähteenkatu); 2. Турку, Вяхяхейккиля, Хиисиляхде (Hiisilähde); 3. Турку, Вирнамяки; 4. Хямеэнкюрё, Тимова сосна; 5. Тампере, Таппарамяки (Тapparamäki); 6. Сяяксмяки, Рапола, Хирвикаллио; 7. Лепаа, Пиккувахопяа (Pikkuvahopää); 8. Лепаa, священный камень; 9. Сипаское священное дерево; 10. Священная роща Пярнамяэ; 11. Камень для подношений Куусалу; 12. Священное дерево Илумяэ; 13. Священный холм Кунда; 14. Священный холм Пуртсе; 15. Священная роща Самма; 16. Священный холм Эбавере; 17. Священная роща Кассинурме; 18. Священная роща Киигеору; 19. Священное дерево Вынну; 20. Таэваскоя; 21. Священная роща Росма; 22. Священная роща Тохкри Тамметсыыр; 23. Священный холм Хинниала Пяэвапёёрамисе; 24. Священный камень Мииксе Яааникиви. 
проводилось в сентябре 2016 года и включало 16 священных мест. Большинство этих мест постепенно наносилось на карту в течение нескольких лет, поэтому общая информация про них была доступна и отражала также изменения в подношениях в священных местах. Полевые исследования в Финляндии проводились в апреле 2017 года на юго-западе страны ${ }^{1}$, где активно используются священные места. В районе Турку гидами служили три члена Taivaannaula. Другие места выбирались на основе информации, представленной во введении проекта hisi и данных информанта из Karhun kansa.

\section{Монеты и серебро}

Эстонские современные подношения в священных местах характеризуются значительной вариативностью, однако доминирующими элементами являются монеты и ленты.

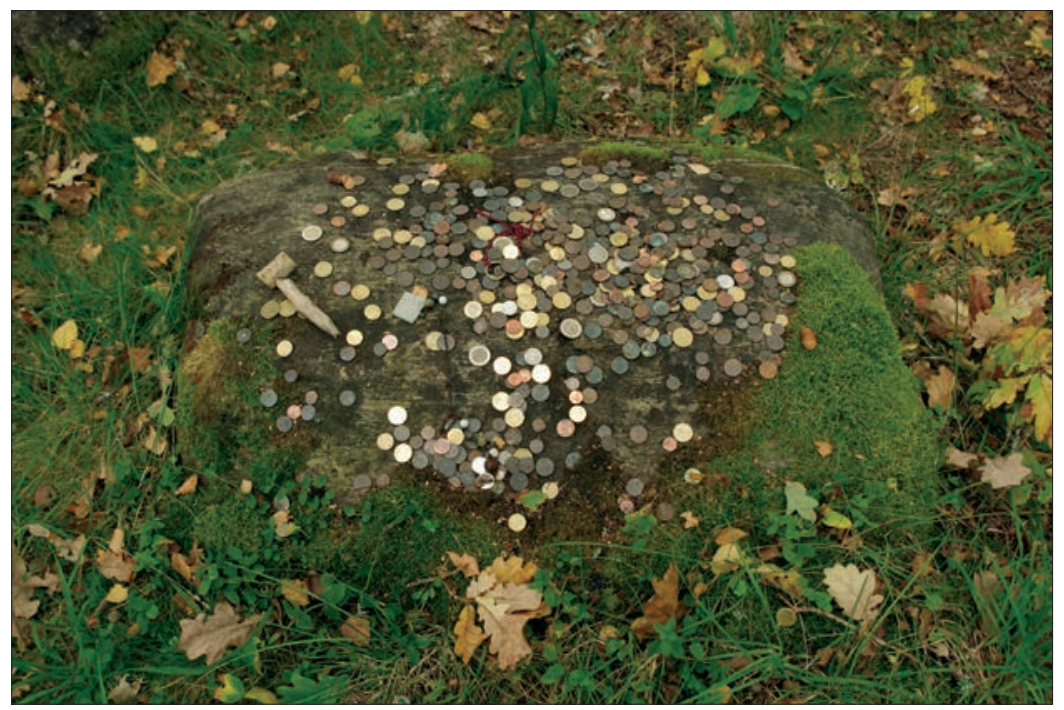

Рисунок 2. Монетные подношения в Тамметсыыр, южная Эстония. Фото Т. Йонукса. 
Оба әлемента являются универсальными подношениями, однако они также рекомендованы местными языческими сообществами. Эти категории также содержат отсылки к эстонским историческим источникам, а также к устной традиции конца XIX - начала XX вв. (см., например, Busch 1937: 65-66; Valk 2001; Jonuks и др. 2010) и некоторые редкие экземпляры сохранились в археологических коллекциях. Монеты начинают чаще встречаться среди подношений с XVII в., когда они потеряли свою ценность, стали дешевле и, соответственно, доступнее для символического использования (Jonuks и др. 2010, 277). С тех пор монеты чаще всего упоминаются как культовые подношения местных крестьян (см., например, Valk 2015). В конце XVIII - XIX вв. подношения монетами стали одной из практик туристов, и монеты стали оставлять в туристических местах, особенно в источниках и колодцах, но также и в пещерах (Laime в печати). Это также самый вероятный вариант происхождения большинства монет из эстонских священных мест в ХХ в. В редких случаях удалось проследить, как монеты использовались в качестве подношений на протяжении XX в. (например, родник Хельме, Tvauri 1997).

Несмотря на очевидность туристических целей, они главным образом прослеживаются в общественных местах, известных широкой аудитории, например, общественных фонтанах. Большое количество монет, оставленных в священных местах, имеет, скорее всего, несколько иной и более личный характер подношения. Формально современные монеты продолжают древние традиции - обычно они имеют низкую номинальную стоимость, наиболее вероятно их оставляют в единичном экземпляре и, согласно доступным нам объяснениям, они являются знаком личного посещения. Другие, более специфические, цели также имеют место: например, лечебная магия, которая также упоминается в фольклорных коллекциях (Valk 2007: 145 ff). В устной традиции монеты описываются как медиатор - в случае кожного заболевания, к поражённому участку кожи прикладывали монету; считалось, что болезнь перейдёт на монету, и когда монету бросали в ручей или оставляли на камне, болезнь также надеялись прикрепить к этому месту. Такие специфические цели могут быть более многочисленными, включая особые очень личные причины оставить монеты в каком-либо месте. 
Большая часть оставленных и документированных монет представлена местными монетами - или эстонские центы и кроны (1992-2011 гг.) или евроценты и евро (с 2011 г.). Советские монеты второй половины XX в. не настолько заметны, частично из-за оседания грунта, но также это может указывать на эпизодическое использование священных мест. В общеизвестных туристических местах, напротив, в больших количествах обнаруживаются советские монеты, оставленные там в процессе туристических поездок. Больше информации можно получить благодаря специфическим монетам, например, шведским или российским. Однако интерпретация тут также может быть двоякой: иностранные монеты можно связывать с обычными туристическими практиками, когда монеты оставляют в месте, где уже есть какие-либо монеты, или иностранные монеты могут также отражать личные цели. Например, значительная эстонская диаспора, покинувшая Эстонию во время Второй мировой войны и живущая в Швеции, часто посещает места своего детства и их окрестности, и в таком случае монета новой родины, оставленная в священном месте страны происхождения, может выступать в качестве духовного связующего звена для этого человека. Тем не менее, существует множество причин для монетных подношений (или другого рода подношений, о чём будет сказано ниже) и, возможно, даже развёрнутые интервью с посетителями священных мест не помогут воссоздать полную картину.

В Финляндии монеты были также найдены у чашечных камней и священной сосны, называемой Тимова сосна. В случае сосны, монеты закладывались в трещины её коры. И чашечные камни, и сосну посещают как туристы, так и современные язычники, поэтому невозможно установить, какая из групп оставила монеты. Все документированные монеты были евро небольшого номинала. Тимова сосна является примером того, как значение священных мест может меняться с течением времени. В фольклорной традиции, она была связана с лечением зубной боли. Считалось, что если человек надавит на больной зуб палкой, а потом оставит эту палку у данной сосны, он также оставит там свою боль. Ещё в 1930-х гг. монетные подношения закладывались в трещины в коре дерева. Также существует фольклорная традиция оставлять черепа медведей и ленты у дерева (более 
подробно см. Kovalainen \& Seppo 2006). Позже эти верования были забыты, в 1990-х гг. сосну показывали школьникам просто как старую сосну. В настоящий момент сосне снова приносят подношения. Возможно, повышению осведомлённости об этом месте способствовал проект hiisi общества Taivaannaula. Современные подношения включают монеты, вышеупомянутые сердечки и вбитые в дерево гвозди.

Когда монеты используются гетерогенной группой людей, соскребленное серебро может рассматриваться как признак реконструкции народных верований. Во время наших полевых исследований мы могли наблюдать, как член организации Taivaannaula соскребал серебро у посещённого нами священного источника. Эта традиция была так важна для него, что когда в одном из мест он заметил, что он забыл свой нож в машине, он вернулся, чтобы взять его. Соскребание серебра в священных

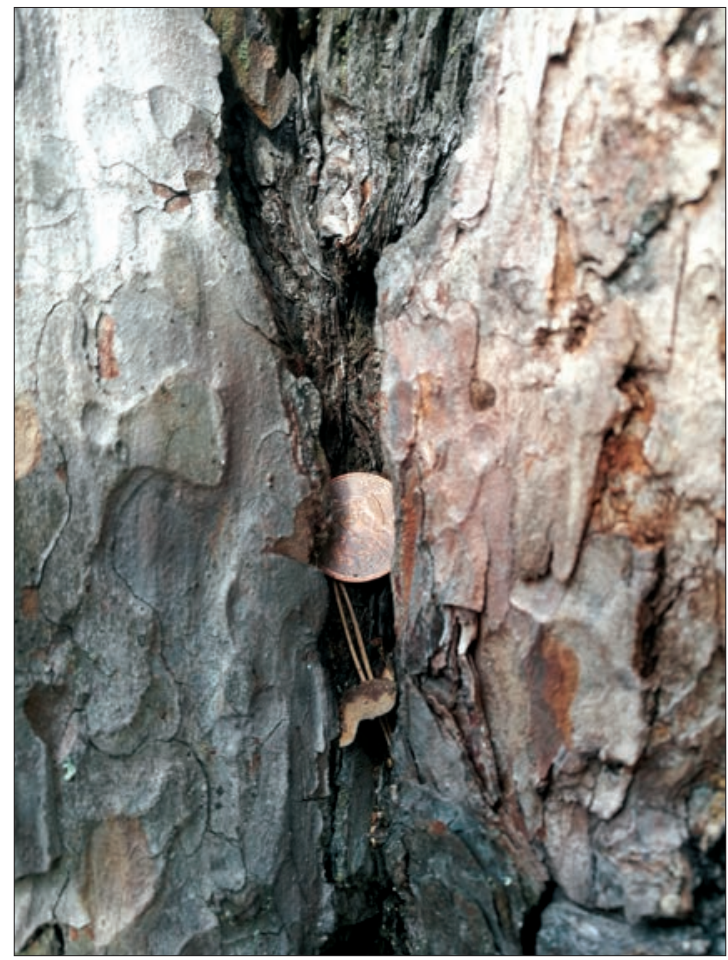

Рисунок 3. Монетные подношения у Тимовой сосны. Фото Т. Айкас. 
местах, особенно у источников, является распространённым и в эстонской языческой традиции. На юге Эстонии, в Таэваскоя, посетителей инструктируют с помощью текста и изображений на информационном стенде, как они могут сделать подношение серебром. Соскребание серебра имеет давнюю историю, на что указывают некоторые серебряные украшения Нового времени в коллекциях Эстонского национального музея, где следы соскребания заметны и подтверждены также историей дарителя (Kuningas 2014). Тем не менее, эту практику сложно наблюдать на природе, не видя самого ритуала в священных местах, так как количество соскребленного серебра мало, и оно рассеяно в окружающей среде.

Рисунок 4.

Соскребание серебра. Фото Т. Айкас.

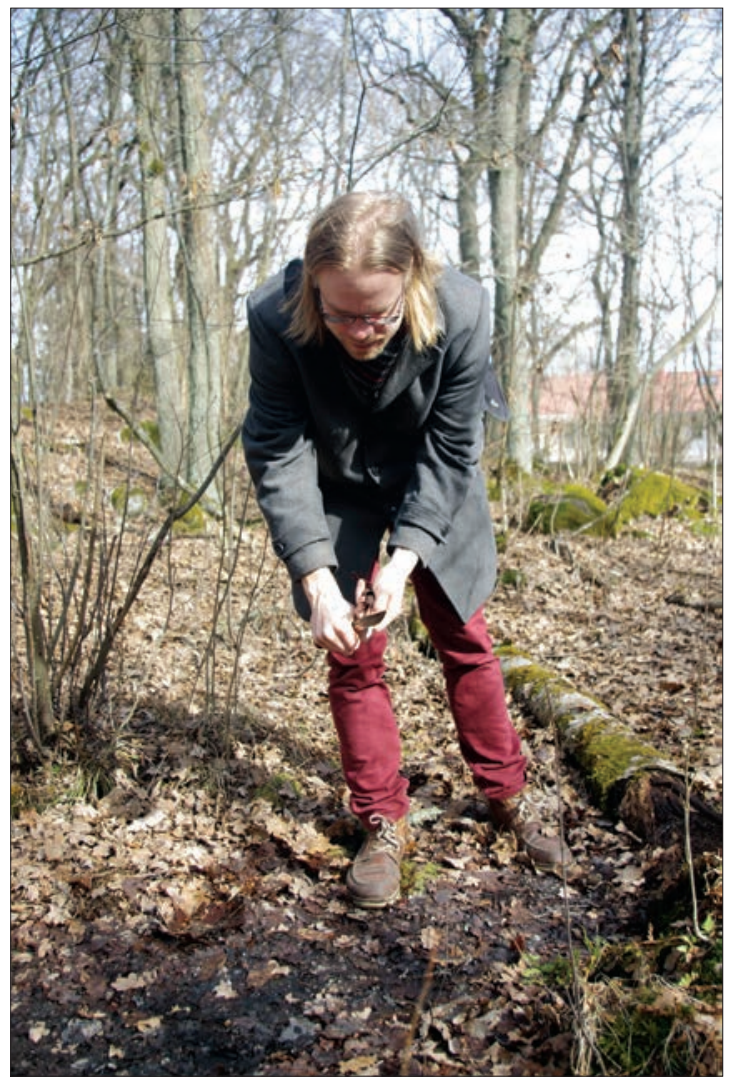




\section{Лоскуты, ленты и другие привязанные} к деревьям предметы

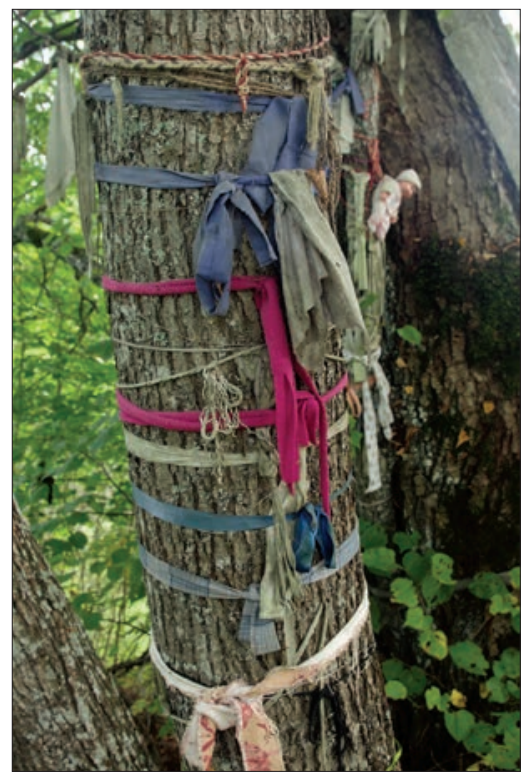

Лоскуты и ленты представляют собой другую обширную и универсальную категорию подношений.

Самые ранние упоминания про них в Эстонии относятся к началу XVII в. (Olearius 1669: 33) и с тех пор они представлены постоянно. В отдельных случаях во время археологических раскопок также были найдены гвозди, использующиеся для закрепления лоскутов на деревьях (Laid 1928). У нас

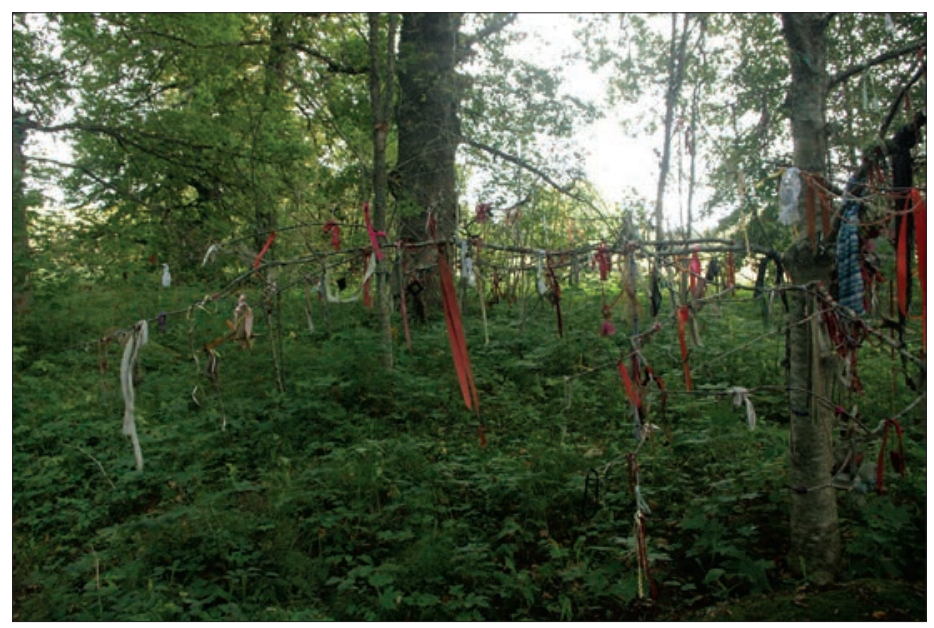

Рисунок 5. Лоскуты и ленты в Илумяә и Пярнамяэ. Фото Т. Йонукса. 
нет документированных примеров, относящихся ко второй половине XX в., использования лоскутов в священных местах. Вполне возможно, что лоскуты и ленты использовались, но документальные свидетельства этого отсутствуют. В то же время, в этот период лоскуты активно использовались во время свадебных церемоний и вешались на столбы и деревья, на которых были гнёзда аистов. Это, очевидно имеет отношение к распространённой фольклорной традиции, в которой аист связан с плодородием и деторождением. Традиция украшать подножия гнёзд аистов разноцветными лоскутами распространена и сегодня, хотя специальных исследований её пока не проводилось. Лоскуты появляются в священных местах снова, начиная с конца 1980-х гг., и с этого времени их количество постоянно растёт.

Учитывая универсальную традицию оставлять лоскуты в разных местах (см., например, Houlbrook 2016) и особенно учитывая её популярность в Эстонии, удивительно, что эта традиция почти не представлена в финских священных местах. Причина отсутствия лоскутов и лент в Финляндии может быть связана с тем фоктом, что возрождение использования священных мест в южной Финляндии - это довольно недавний френомен. Эта традиция, однако, может начать распространяться и в Финляндии. Она приобрела некоторую популярность после начала проекта hiisi в 2013 г. Наш информант из сообщества Taivaannaula упомянул, что традиция вешать ленты на священные деревья введена на Вирмапыхя в Йямся, людям предлагается оставить лоскуты на деревьях. Так мы можем сейчас отслеживать процесс внедрения языческой традиции в фринский контекст, что в последующем может быть описано как исконная традиция.

Современное языческое сообщество в Эстонии также играет важную роль в популяризации лоскутов, утверждая, что это старая и беспрерывная традиция. В начале 1990-х гг. ленты рекомендовалось вешать в священных местах с отсылками к фольклору и описаниям периода раннего Нового времени. Эти рекомендации были с удовольствием приняты к сведению и начали активно внедряться в жизнь в 1990-е гг. Развитие традиции вышло из-под контроля начали использоваться разнообразные материалы, в том числе полиэтиленовые пакеты, отражатели и т.д. - все подручные и дешёвые материалы. 


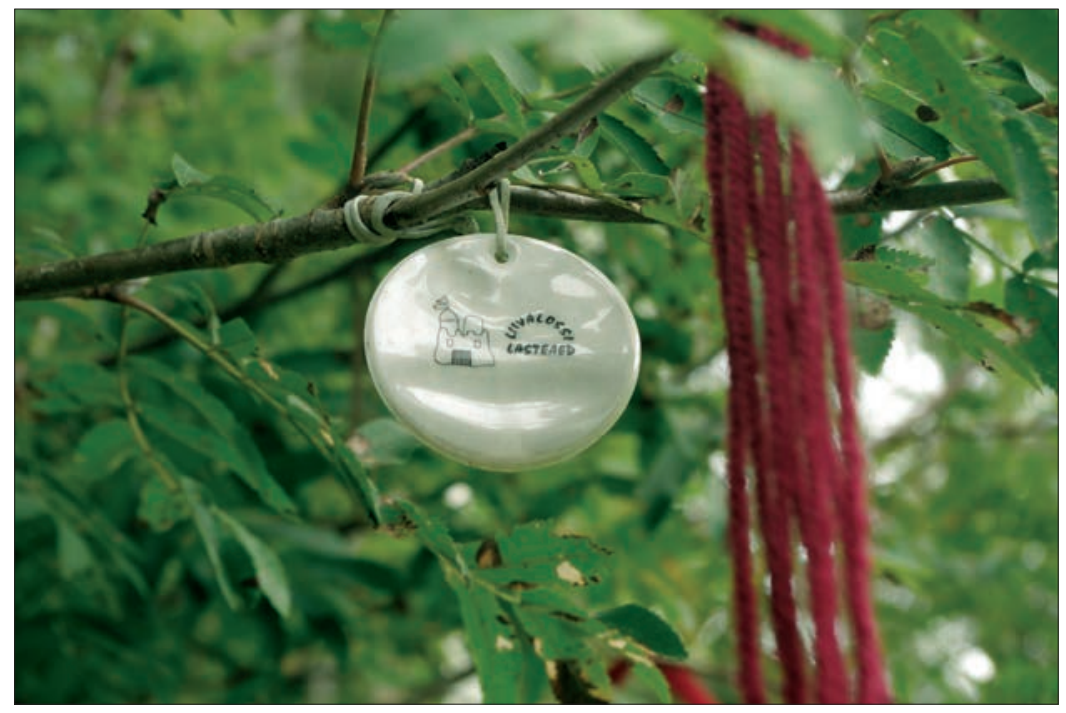

Рисунок 6. Отражатель с названием детского сада Лиивалосси в Кассинурме. Подношение обычного посетителя или организованная поездка детского сада? Фото Т. Йонукса.

В результате, священные места были и до сих продолжают быть заваленными лоскутами наряду с другими разнообразными объектами.

Конечно, обычай вешать лоскуты на деревья нельзя ассоциировать с более широким распространением традиций современного язычества. Значительное влияние оказали универсальные туристические традиции, но люди также (ре)интерпретировали то, что они уже видят. Последнее, возможно, является одним из наиболее влиятельных фракторов, стимули- рующих людей оставлять различные привязываемые объекты, которые иногда выделяются очевидной личной принадлежностью. С 2000-х гг. сообщество современных язычников начало рекомендовать использовать только органические материалы, что позже трансформировалось в более личную практику, в которой лоскуты предполагалось ткать самим, желательно из красной пряжи.

Многочисленные самодельные лоскуты, оставленные с тех пор, указывают на активное принятие этой рекомендации 
Рисунок 7. Пример разных материалов и объектов, подвешенных на дереве в Пярнамяэ. Фото Т. Йонукса.

Рисунок 8. Самодельные ленты в Киигеору. Фото Т. Йонукса.
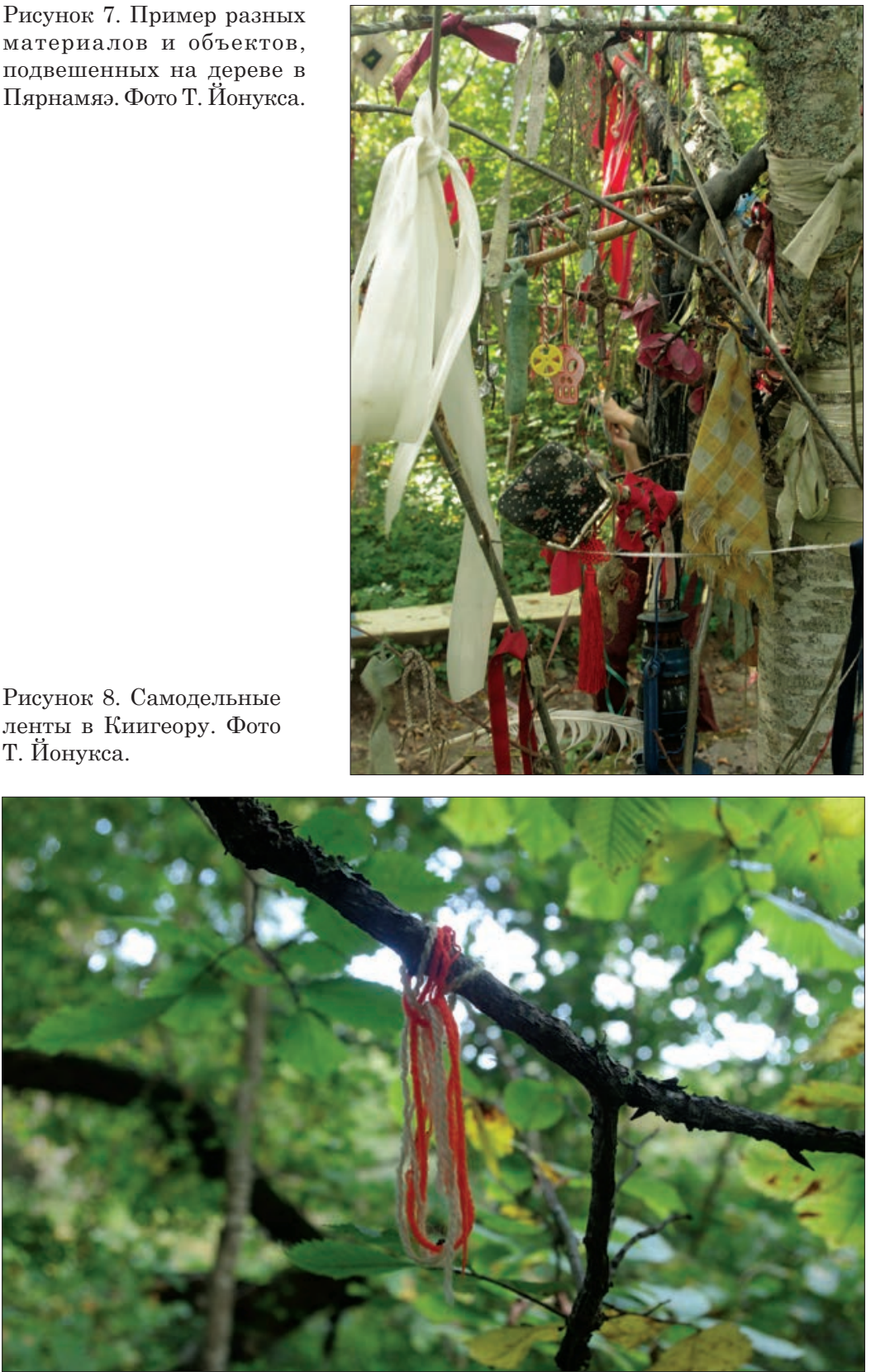
и активную роль группы современных язычников в формировании практик людей в священных местах, хотя полиэтиленовые пакеты и другие синтетические материалы всё ещё встречаются.

В Эстонии лоскуты и пряжа могут быть не только привязаны к деревьям, но также они могут быть переплетены более сложным образом, возможно, неся в себе символическое значение. В контексте приоритета органических материалов, появились также плетёные изделия из природных и местных материалов, таких как кора, травинки, шишки и т.д.
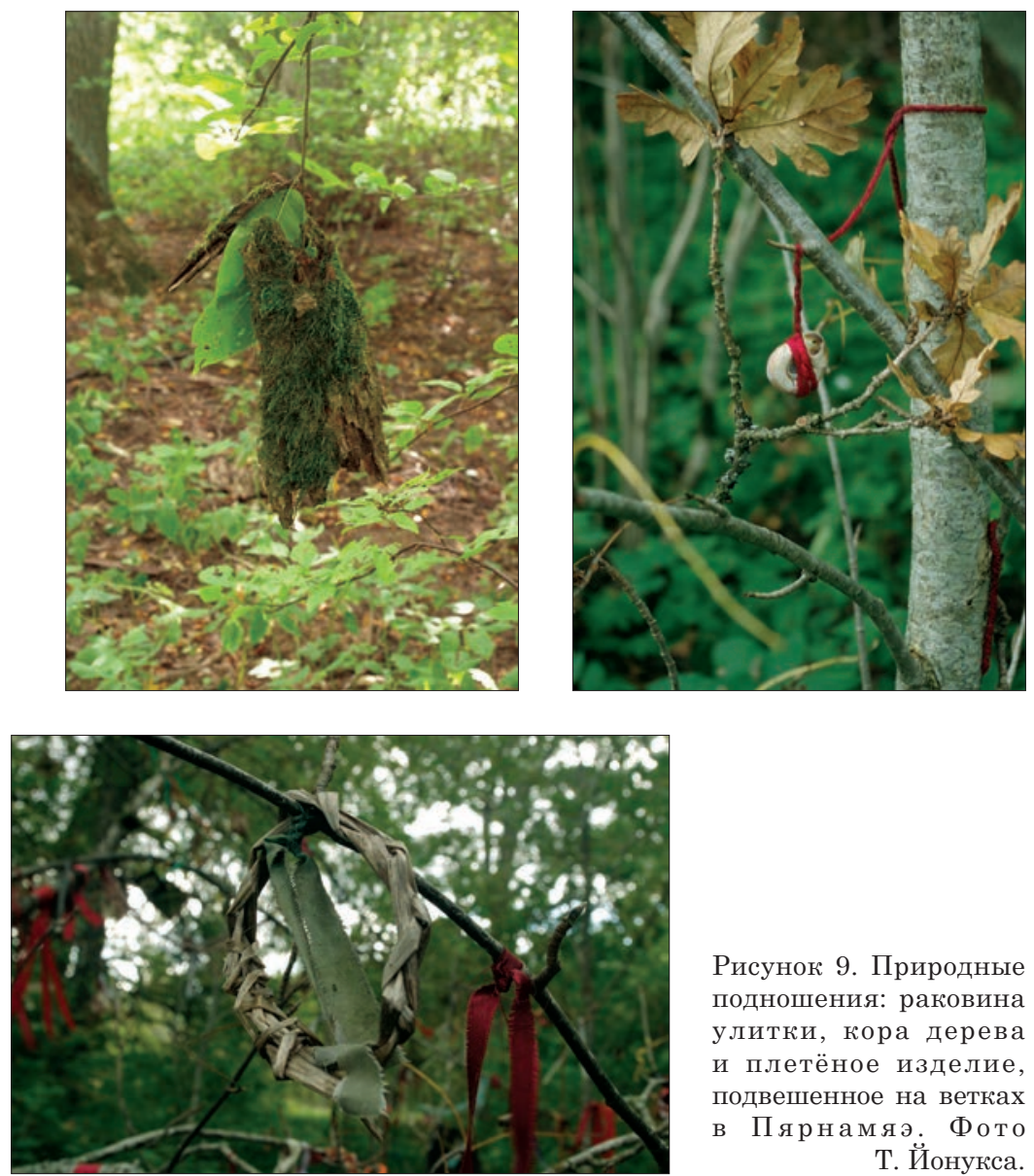

Рисунок 9. Природные подношения: раковина улитки, кора дерева и плетёное изделие, подвешенное на ветках в Пярнамяэ. Фото Т. Йонукса. 
Такие материалы очень редко упоминаются в эстонском фольклоре, но органические и природные материалы очень гармонично сочетаются с современной идеологией, подчёркивающей экологичный и разумный подходы. Для учёных, работающих с материальными предметами, такие подношения поднимают интересный вопрос о том, как определить сознательные подношения по прошествии некоторого времени. Это также хороший пример для напоминания нам о том, что только часть религиозных подношений сохраняется. Интерпретируя любое место, нужно иметь в виду, что первоначальная выборка подношений могла быть значительно шире, включая органические материалы, еду и т.д.

\section{Детские игрушки}

Вопрос осознанности и цели возникает также в случае некоторых других видов подношений. В течение последних нескольких лет в священных местах Эстонии в качестве подношений появляются детские игрушки. Среди них мы можем найти, например, игрушечные машинки, кукол и плюшевых мишек.

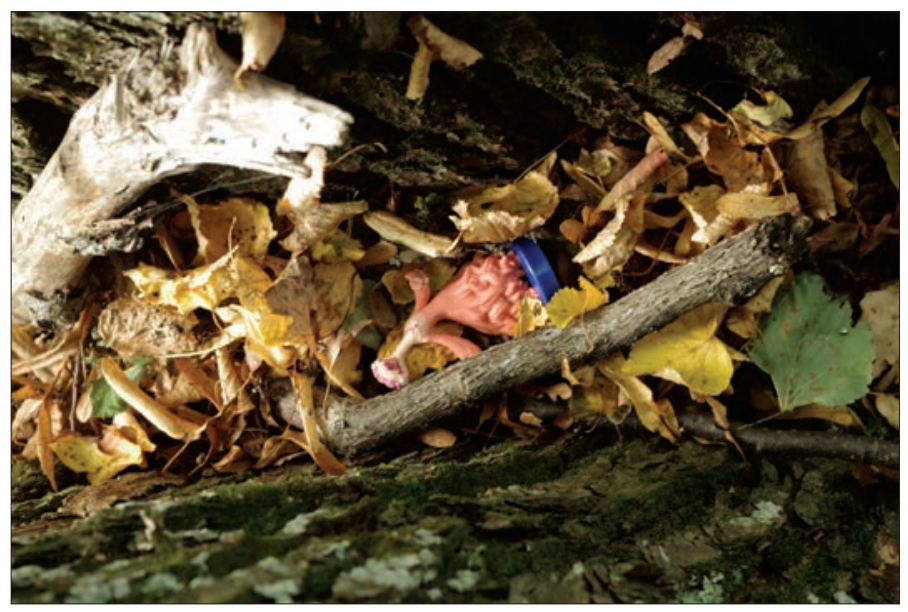

Рисунок 10. Детская игрушечная фигурка, спрятанная между двумя стволами деревьев в Илумяә. Фото Т. Йонукса. 
В данный момент неизвестно, кто оставил такие подношения и зачем. Были ли это дети или взрослые, были ли они членами какого-либо духовного сообщества или просто обычными посетителями? Более вероятно, что дети духовного сообщества будут перенимать привычки взрослых этого же сообщества и, соответственно, можно ожидать органических подношений, а не обычных пластмассовых игрушек. Исследование, проведённое в Америке, показывает, что детям свойственно как минимум перенимать языческую духовность своих родителей (Fennell \& Wildman-Hanlon 2017). Учитывая, насколько важным является «правильное поведение» и воспитание для последователей Maausk, можно также предположить, что их дети будут следовать привычкам родителей. Самые частые и распространённые игрушки могут скорее отражать случайное посещение какогонибудь ребёнка, который оставил игрушку на месте, просто следуя уже существующей традищии.

\section{Еда для духов}

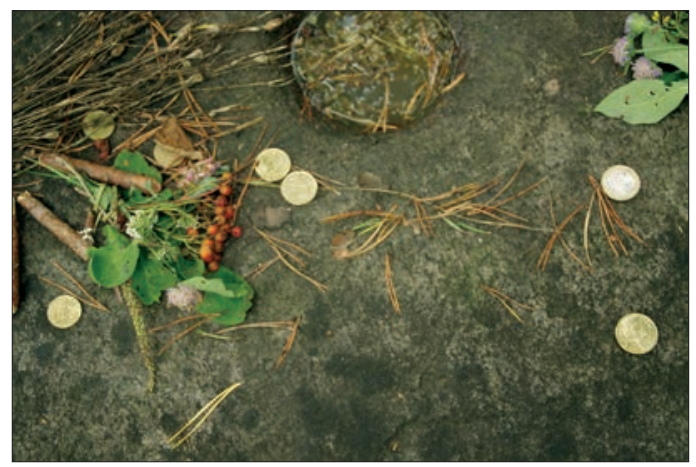

Согласно данным фольклора, один из наиболее распространённых материалов, который оставляют в священных местах, это еда (пример см. в Valk (ред.) 2007).

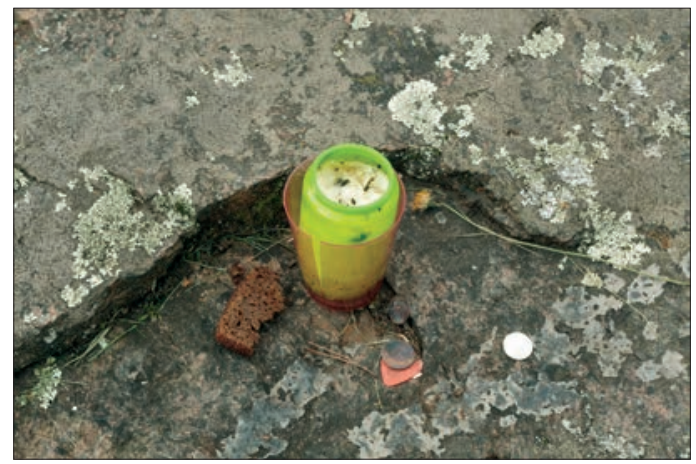

Рисунок 11. Хлеб, свечи и монета в Кассинурме и яблоко и ягоды на жертвенном камне в Самма. Фото Т. Йонукса. 
Традиционно в фольклоре упоминаются ягоды, хлеб и пиво, за ними идут мясо и мясные продукты, яйца, молоко и т.д. Однако по очевидным причинам остатки еды редко сохраняются. Чаще всего описания просто упоминают съестные подношения, часто оставляя впечатление, что информанты знали о традиции, но не видели её сами. Личные эмоции добавляются редко. В 1889 г. местная жительница описывала священную рощу в центральной Эстонии следующим образом: «Люди приносили ему [богу Хиис/Хиэ] всевозможные вещи, новый урожай, шерсть, мясо, вареники, колбасу, хлеб, булки, селёдку, соль и т.д. с мыслью и молитвой о том, что Хиэ защитит их и отведёт от них невзгоды, которые преследуют живых. Чтобы не пускать животных на святое место, вокруг него был построен высокий забор. И всё равно ниши для подношений выглядели омерзительно, с кусками ткани и мяса и другой еды, они начинали вонять. Вот что говорят люди» (Н II 17, 127/9 (2)). Такое эмоциональное описание зловонных подношений показывает, что информант видела подношения едой собственными глазами.

Согласно традиции современных язычников, подношение хлебом, кашей и яйцами является частой практикой. Нередко еду оставляют во время календарных или общественных ритуалов. В Вирнамяки, Финляндия, еда была замечена в чашевидной лунке на валуне после летнего солнцестояния (Hukantaival, личное сообщение 2017). Однако такой вид подношений быстро исчезает, и не остаётся даже яичной скорлупы. Уникальный случай наблюдался во время этого исследования в Финляндии, где сахар насыпали в чашевидные лунки валуна в Рапола, Caаксмаки. В дополнение к этому, остатки неопознанного сушёного фррукта или овоща были найдены в том же месте и хлеб был замечен на том же чашечном валуне ранее. Несомненно, еда была и остаётся типичным материалом для подношений, хотя она быстро исчезает и её сложно изучать. В редких случаях посуда указывает на подношение пищи. На Пяэвапёэрамисемяги в южной Эстонии уже установлены ёмкости для каши и горшки.

Это уникальный объект, так как в связи с его труднодоступностью это не туристическое место и главным образом там присутствует сообщество Maausulised. Соответственно, оборудование для приготовления ритуальной каши хранится на месте, чтобы оно было всегда доступно. 


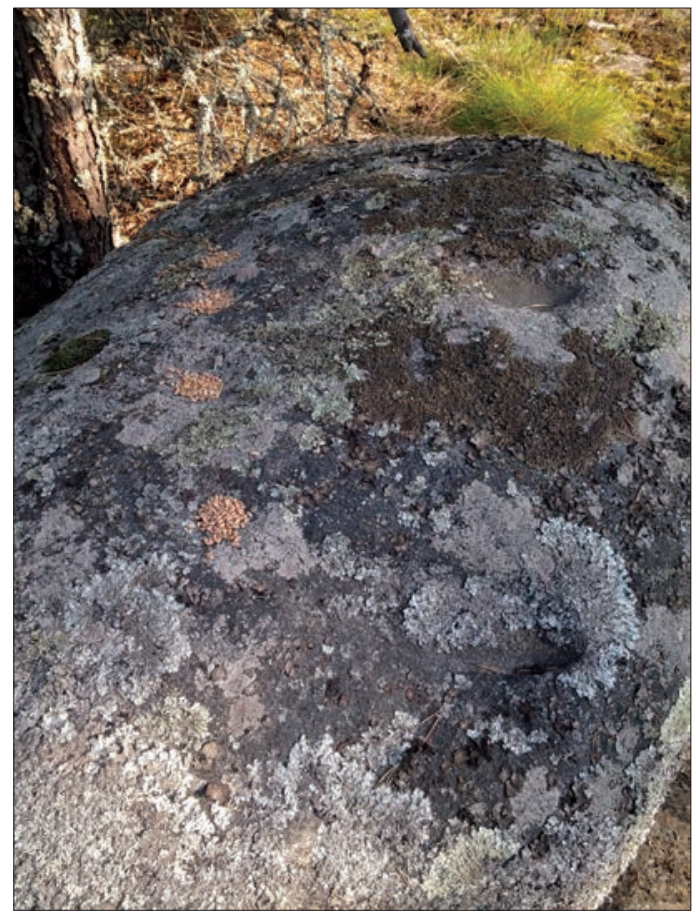

Рисунок 12. Зерно в чашевидных лунках валуна в Вирнамяки. Фото С. Хукантаивал (S. Hukantaival).

В некоторых эстонских священных местах оставляют конфеты. У корней липы Илумяэ мы заметил и небольшую корзинку, некогда полную конфет.

К моменту нашего посещения, конфет не осталось, лежали только пустые обёртки. Выемка в углу корзинки указывала на то, что мышь съела конфеты, но это также можно интерпретировать как принятие подношения духом места. В некоторых местах конфеты находят в Финляндии (например, Вирнамяки, личное сообщение от Helena Ruotsala). Есть также этнографические сведения о традиции оставлять конфеты духам деревьев среди пожилых людей народа ижора (Arukask 2017). В последнем случае причина, по которой для подношения выбраны конфеты, схожа с факторами, обуславливающими использование монет и лент: конфеты довольно дёшевы и удобны, благодаря обёрткам их можно легко хранить даже в карманах и, с точки зрения исторической памяти, у конфет есть определённая ценностная коннотация. Всё это вместе делает конфеты очень удобным объектом для подношения духам. 

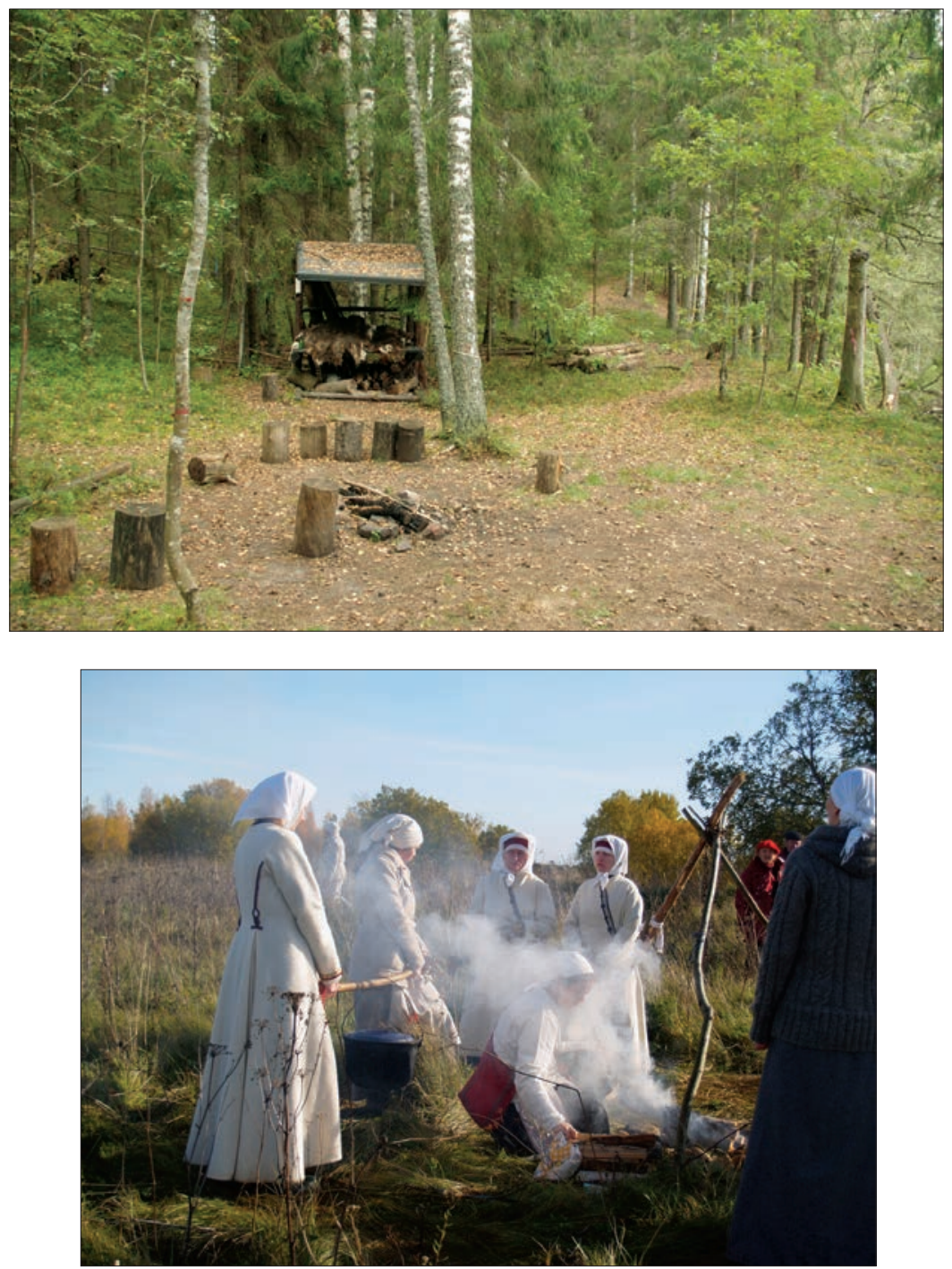

Рисунок 13. Ритуальное место у подножия холма Пяэвапёёрамисе. Mex и горшки хранятся в укрытии на заднем плане. Фото Т. Йонукса. Приготовление ритуальной каши на священном холме Кунда членами Maavalla Koda. Фото Х. Майберг (H. Maiberg). 


\section{Любовь и чары}

В некоторых случаях наиболее ярко выраженной может быть любовная магия. Лучшим примером этому является маленькая корзинка с подношением из яблок и запиской с любовным заклинанием на камне под Сипаской липой.

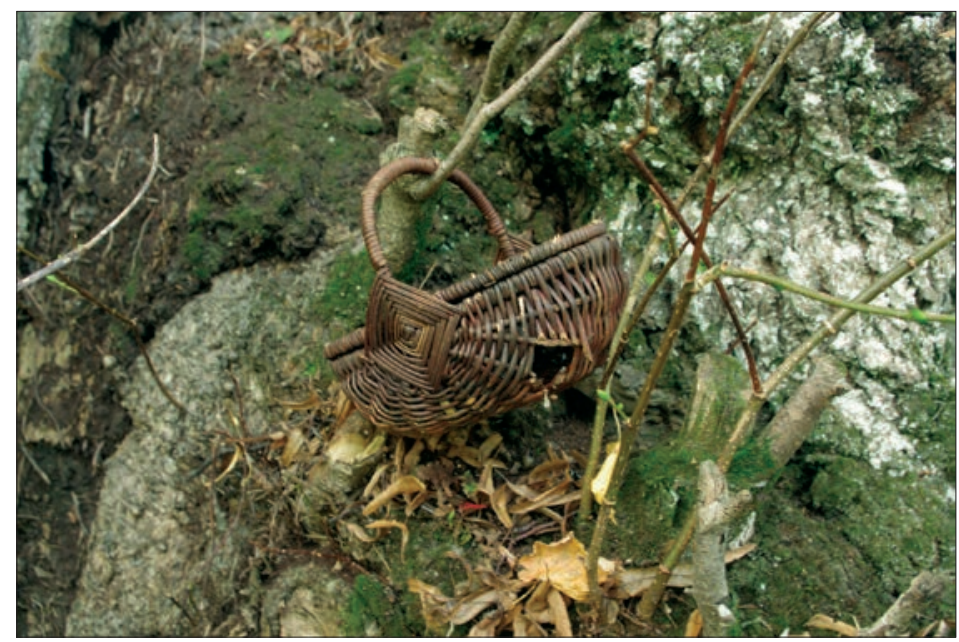

Рисунок 14. Корзина с пустыми обёртками от конфет в Илумяэ. Обратите внимание на мышиную дыру в углу.

Некоторые другие примеры также можно связать с любовной магией или её юмористическими интерпретациями. На священном дереве Вынну Мяэсуитсу была повешена пара мужских носков, а на соседней ветке была оставлена пара женских чулок.

Впоследствии на этом дереве появились и другие пары чулок, хорошо проиллюстрировав идею о том, как одно подношение может создать традицию, которая по-своему интерпретируется другими посетителями места. Однако в отличие от примера с Сипаской липой, цель подношений не представлена однозначно, и можно только предполагать, повязали ли носки и чулки по причинам, связанным с любовью/плодородием, просто для забавы, чтобы реинтерпретировать более ранние подношения 


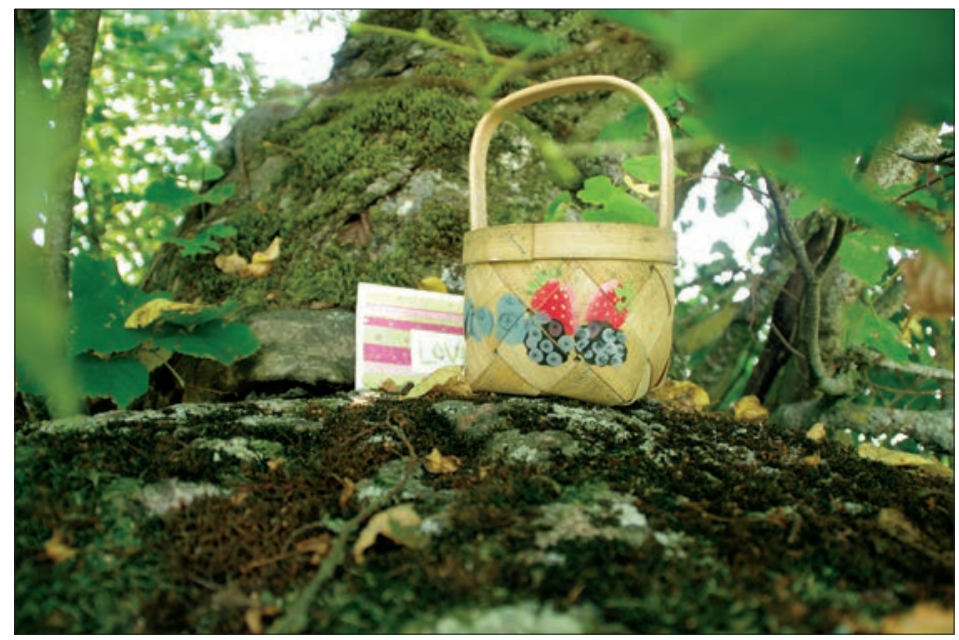

Рисунок 15. Корзина с яблоками и открытка в Сипа. Фото Т. Йонукса. На обратной стороне открытки - любовные чары:

Мы возьмём жёлтую глину, дорогой, и вылепим две фригуры - тебя и меня. Теперь скомкаем их снова в безликую массу и вылепим снова - тебя и меня! Половина тебя - это я, и половина меня - ты!

или по другим причинам. Более того, оставление частей одежды и нижнего белья в священных местах не является исключительно эстонским феноменом, оно было отмечено и в других странах. Возможно, также переплетённые браслеты, привязанные к ветвям деревьям в разных местах Эстонии, могут быть связаны с любовными или личными взаимоотношениями.

Рисунок 16. Женские чулки в Вынну Мяәсуитсу. Фото Т. Йонукса.

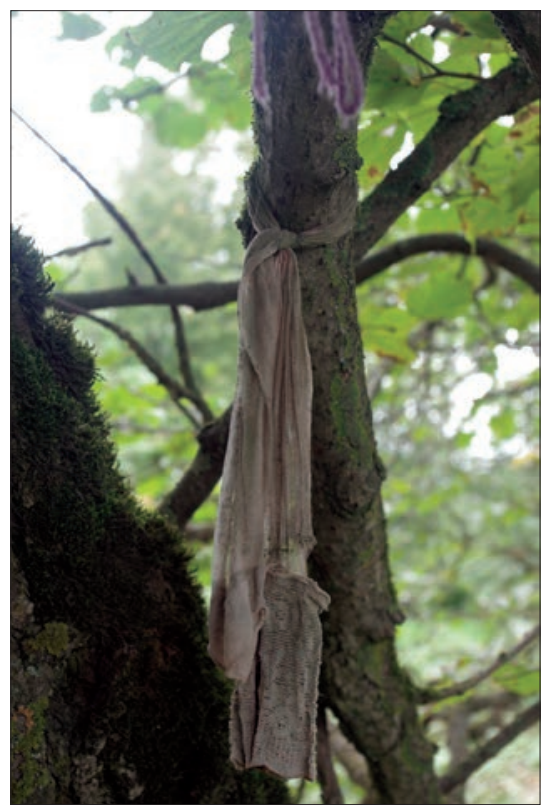


На Тимовой сосне в Хямеэнкюрё, Финляндия, бирюзовое стеклянное сердечко было вставлено в углубление в дереве.

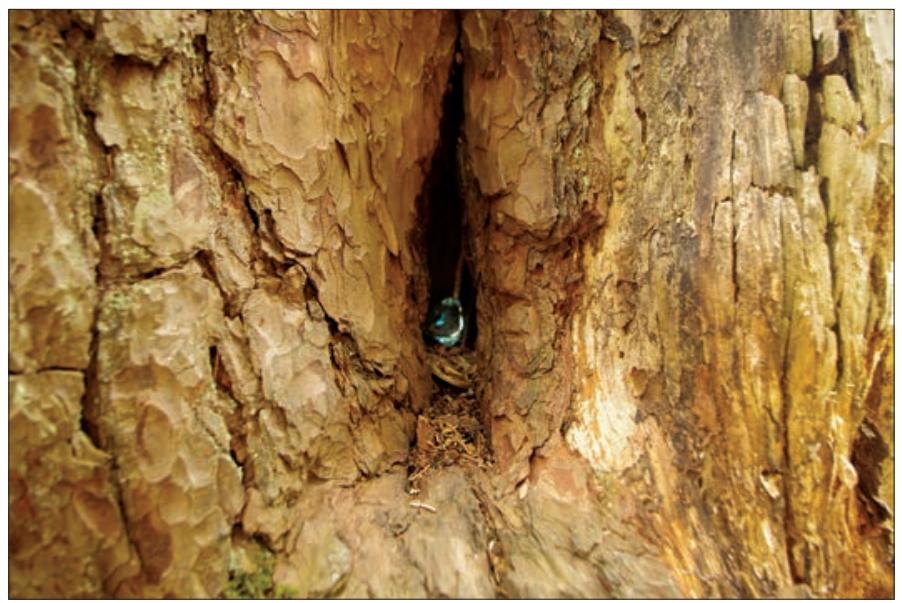

Рисунок 17. Кулон в форме сердца и монеты у Тимовой сосны. Фото Т. Йонукса.

Это также может служить примером подношения, связанного с любовными отношениями. Несомненно, любовь может также проявляться в отношении божества, духа или природы.

Большая часть любовной магии представляется результатом личных ритуалов. В отдельных случаях могут сохраниться также остатки других, более сложных ритуалов. На вершине холма Эбавере, места с достаточно сложной историей (подробнее cм. Jonuks и др. в печати) было построено святилище. Его центр составляет алтарь, сделанный из трёх больших камней, и около него в 2014 г. были обнаружены остатки сожжённых светлых волос. Похожий пример ритуального сжигания собственных волос был документирован на шаманском фестивале «Исогайса» в северной Норвегии (Айкас и др. в печати). Вероятно, сжигание волос и ногтей является частью магических действий в разных религиозных системах и, следовательно, может происходить и чаще, но следы его не сохраняются или не документируются. 


\section{Магия, эзотерика, синкретизм и христианство}

Священные места часто содержат материальные отсылки к магическому и әзотерическому мировоззрениям. Интересно отметить, что в нашем исследовании все примеры этого были найдены в Эстонии и ни одного не было отмечено в Финляндии. Мы зафиксировали висящие на ветвях деревьях круглые подвески со знаками каббалы в нескольких местах Эстонии.

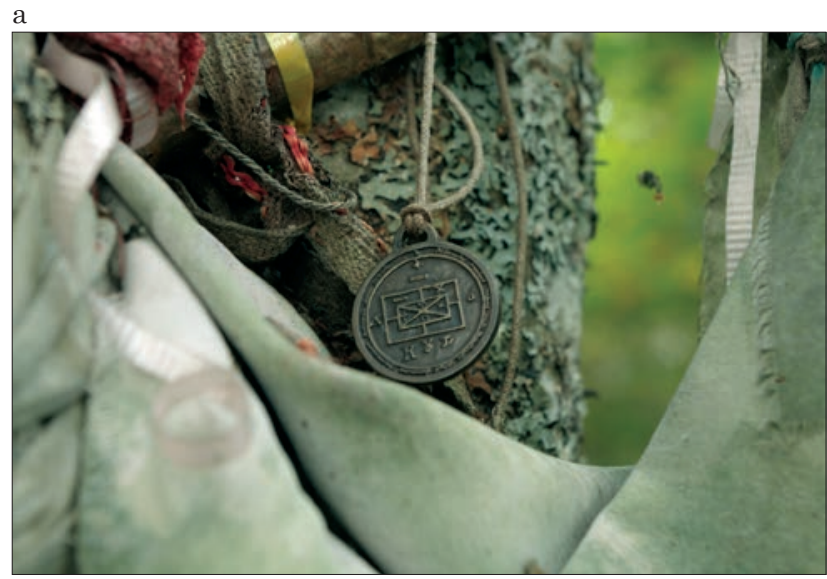

б

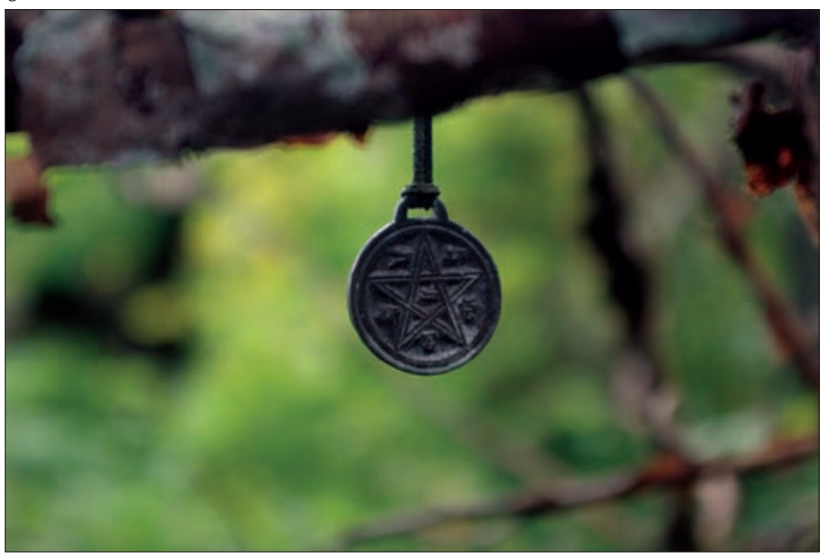

Рисунок 18. Подвески каббалы в священных рощах Пярнамяэ (a) и Киигеору (б). Фото Т. Йонукса. 
Именно эти объекты наиболее тесно связаны с религиозными системами, отличными от народной культуры. Подсвечник в форме кельтского креста, увенчанный фригурой, похожей на летучую мышь, у Сипаской липы может иметь отношение к сатанистским традициям, также чужеродным традиционной культуре Эстонии. Наиболее распространённые нетрадиционные подношения - это различные кристаллы и породы. Наиболее вероятным источником вдохновения для использования этих пород в качестве подношения являются различные веяния, в том числе современный эзотеризм, Нью Эйдж, современное и исконное язычество и другие духовные движения, где сверхъ-

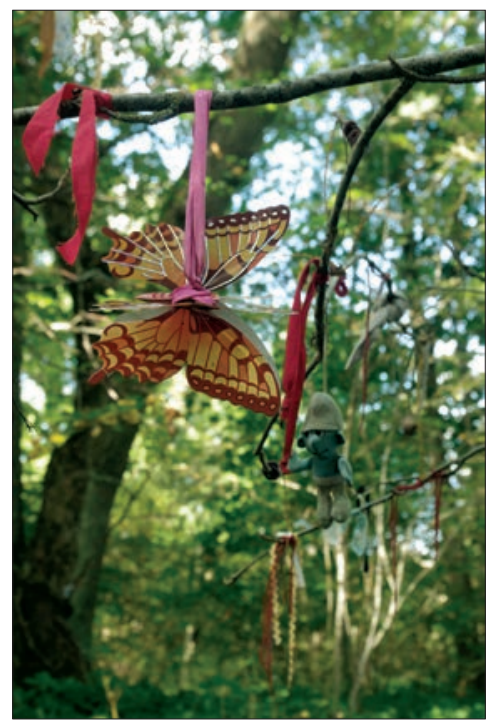
естественные сила и әнергия приписываются разного рода кристаллам (например, Melton 2013). Различные современные духовные движения возможно также стоят за фигурками ангелов.

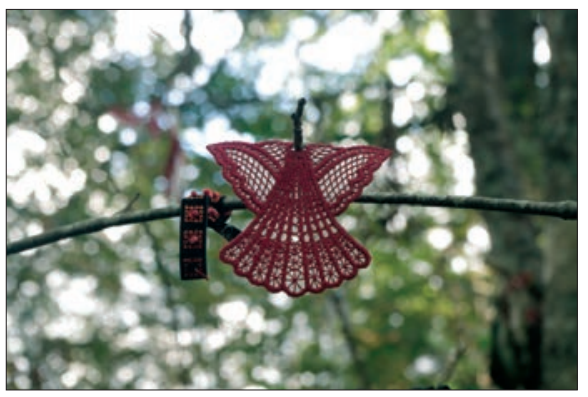

Рисунок 19. Бабочки, смурфики и ангелыв Пярнамяэ. Фото Т. Йонукса.

Несмотря на то, что ангелы напрямую ассоциируются с христианской религией, они также играют важную роль в Нью Эйдж, где ангелы представляют защитных духов. Такого рода переплетение очень разных духовных движений также заметно в так называемых украшениях Ojo de Dios (Глаз Бога), найденных в нескольких местах. 


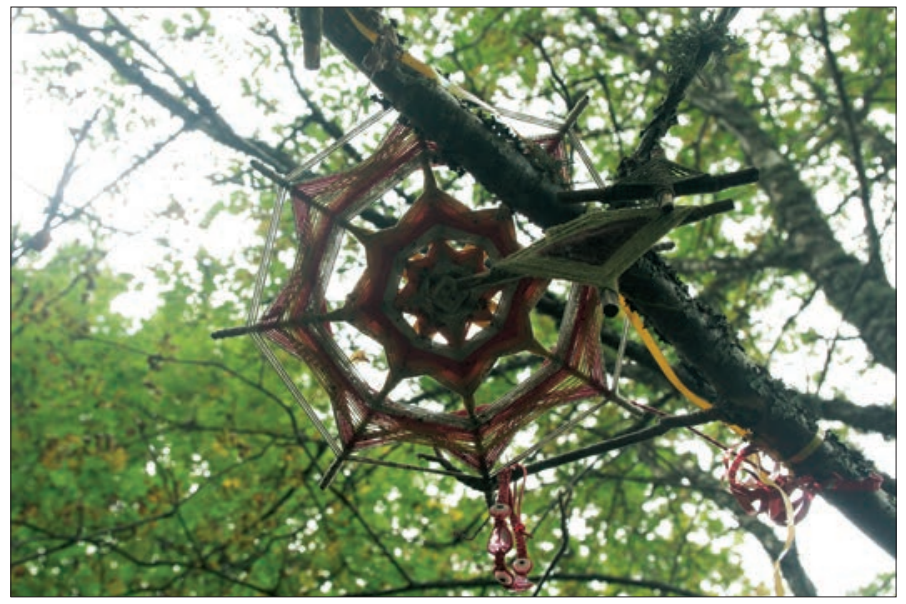

Рисунок 20. Ojo de dios в Пярнамяэ. Фото Т. Йонукса.

Такого рода плетёные объекты из прутьев традиционно делают в Мексике и Боливии и кладут на алтарь. Изначально Ojo de Dios символизировал способность видеть невидимое, его четыре угла представляли землю, воздух, воду и огонь. Сегодня христиане по всему миру популяризировали это ремесло как символ единственного Бога. Однако похожие мотивы можно было найти в разных частях мира, и даже в Эстонии и Финляндии, где они использовались в народной культуре в качестве декораций на Майских деревьях в Финляндии и на Рождество, Новый год и другие праздники в Эстонии (Potts 1982: 60-67). Но эти объекты также вводятся в языческие и духовные практики, которые наиболее вероятно и привели к их появлению в священных местах Эстонии. Важная роль центрально- и южноамериканских духовных практик в современном прибалтийском язычестве описана также в Литве (Aleknaitè 2017). Однако поскольку эстонские примеры, возможно, являются результатом отдельного и личного посещения, их сложно интерпретировать в рамках более узкого контекста, а не общего эзотерического влияния.

Было также зафиксировано несколько примеров отсылок к христианству в священных местах. Они включали русские православные иконы, висящие на ветвях в священной роще Пярнамяэ, но отдельные нательные кресты также были замечены в нескольких других местах. 

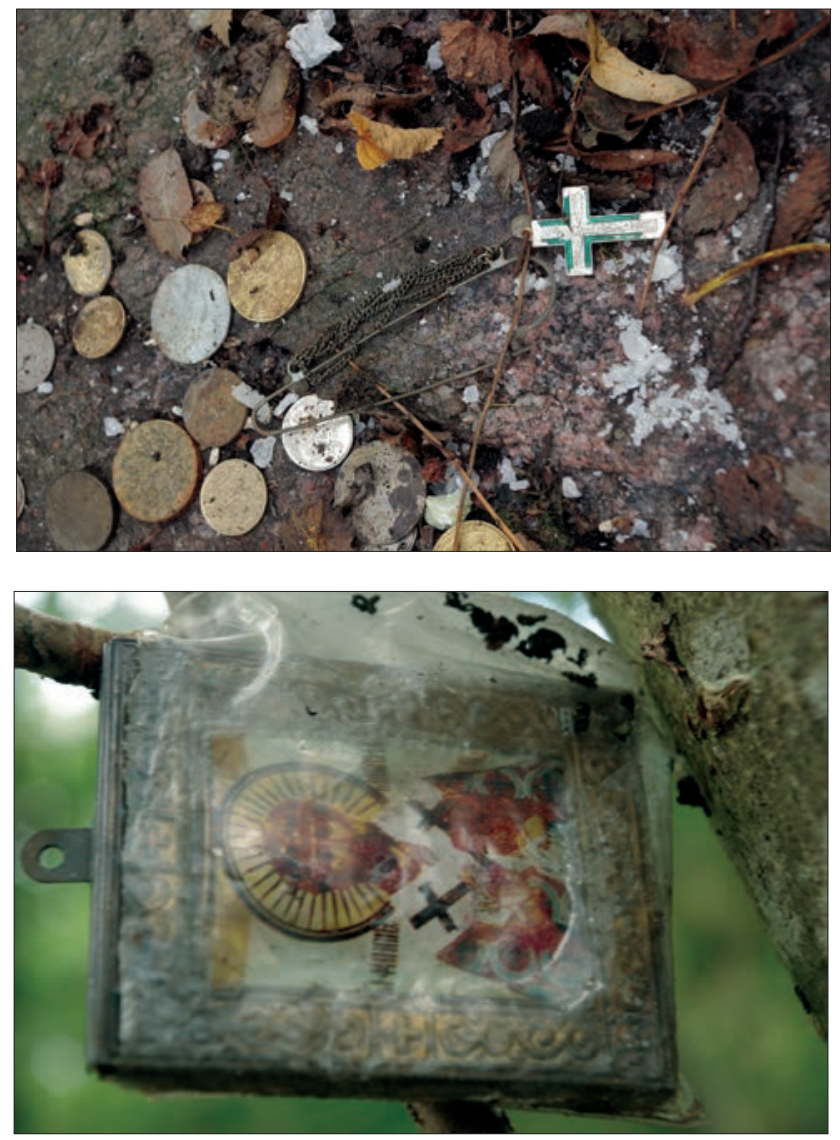

Рисунок 21. Шейный крестик и икона в полиэтиленовом пакете в Пярнамяэ. Фото Т. Йонукса.

Например, Тиина Айкас установила, что подобные примеры замечены на саамских местах подношений в северной Финляндии, где серебряный кулон в форме креста и брошюра под названием «Иисус Христос ваш Спаситель» были оставлены на культовых камнях. Хотя последнее можно рассматривать как попытку христианизовать «языческое» священное место, другие интерпретация этого и подобных эстонских примеров включают идею об оставлении христианской веры или репрезентацию 
синкретичной веры. Кэтрин Раунтри (Kathryn Rountree) пишет о том, что люди могут сочетать христианские и языческие әлементы веры в своей идентичности: «Некоторые люди сейчас утверждают о наличии у них двух идентичностей, христианской и языческой, или христианско-языческой идентичности, сочетающей элементы христианских и языческих ритуалов, отсюда происходит термин 'христианская ведьма'» (Rountree 2014: 82). Исторически христианские власти всегда противостояли почитанию природных объектов в Эстонии и Финляндии, считая это язычеством. Тем не менее, из-за размывающихся границ разных религий, такой острой конфронтации больше нет. Священник прихода Юри в северной Эстонии выступил с инициативой защищать холм Тыдва как священное место. Главные аргументы в поддержку защиты холма состояли в том, что священное место является символом национальной идентичности и что его природная ценность переплетена с его значимостью для местной истории. В результате разные религиозные подтексты не вызвали конфликта на священном месте, поскольку оно воспринималось не как языческий объект, а как часть эстонского культурного наследия. Таким образом, христианские кресты и иконы в священных рощах не обязательно символизируют противостояние, но могут быть обычным знаком посещения места, как и монеты, ленты и другие распространённые предметы.

\section{Заключение}

Таким образом, мы зафиксировали значительное разнообразие различных подношений в местах, считающихся священными в устном фольклоре. В качестве предварительного результата можно выделить два аспекта, требующих дальнейшего обсуждения. Во-первых, несмотря на подчёркивающееся обычно сходство между Финляндией и Эстонией, особенно в сфере народной культуры, древней истории и отношения к природе, подношения в священных местах существенно отличаются. Во-вторых, в то время как подношения в Финляндии представляют собой или традиционную еду, или распространённые сейчас монеты и ленты, подношения в Эстонии очень разнообразны и представляют также гетерогенную аудиторию посетителей этих мест. 
Эстонские священные места часто связываются исключительно с сообществом maausulised. Отчасти это результат активной деятельности этого языческого сообщества по публикации популярных статей в местных газетах и журналах (по их словам, за 2008-2012 гг. было опубликовано более 700 газетных статей и интервью, см. http://hiis.ee/files/Koondaruanne_2008_2012.pdf) и, таким образом, формированию более широкого взгляда на священные места. С другой стороны, maausulised также широко представлены в научных трудах, что является закономерным ввиду того, что организацию изучать легче, чем более широкую аудиторию. Однако в то же время священные места считаются важными и для других групп, часто довольно размытых. Чаще всего в популярных статьях упоминаются просто «эстонцы» и природные священные места называются важными для эстонской национальной идентичности, особенно в последние десятилетия. В обсуждениях священные места тесно ассоциируются с эстонской историей и национальной идентичностью. Следовательно, священные места, их посещение и сопутствующее оставление подношений стало культурным наследием, и большинство посетителей не связывают эту практику с языческим сообществом, но рассматривают её как выражение своих национальных чувств. Вероятнее всего, этой связью и обусловлена высокая популярность священных мест в Эстонии и даже отсутствие религиозного конфликта с христианами и поддержка со стороны клира таких языческих мест.

Но природа и священные места стали важны и для других религиозных групп, например, различных духовных практик или некоторых христианских конфессий. В нашей выборке такая многоликая аудитория посетителей священных мест наиболее очевидна на примере Пярнамяэ вблизи Таллинна. Такое расположение делает это место также привлекательным и легко доступным для людей, живущих в городе и интересующихся духовными практиками. Кроме частых и обычных духовных практик это место используется для шаманских ритуалов (см., например, https://www.youtube.com/watch?v=AGpHNC62GPM). Однако эти группы, часто представленные или отдельными посетителями, или редкими событиями, недостаточно освещены в исследованиях, вследствие чего сформировался ограниченный взгляд на посетителей священных мест. 
Ситуация в Финляндии, однако, весьма отличается. Несмотря на наличие нескольких языческих сообществ в Финляндии, их деятельность считается религиозной, а национальная идентичность не так тесно связана со священными местами. Возможно, это также причина того, почему количество священных мест, активно использующихся для подношений, намного меньше, чем в Эстонии. Это особенно примечательно, так как единственное сравнительное исследование об эстонских и фринских священных местах (hiis), проведённое Мауно Коски (1967, 1970), свидетельствует о том, что количество этих мест примерно равно в обеих странах. Заметно также полное отсутствие или весьма малое количество подношений, ассоциирующееся с другими духовными группами в Финляндии. Наиболее вероятным объяснением этому являются разные взгляды на священные места в Эстонии и Финляндии: природные священные места Эстонии широко и позитивно представлены в СМИ, что побуждает обычных людей использовать их. В то же время такие статьи намного более редки в Финляндии. Поэтому общие сходства между этими двумя странами, часто подчёркиваемые в научных исследованиях, слабо влияют на использование священных мест. Большее влияние имеет деятельность и заметность современных языческих сообществ в СМИ и социальных сетях, что рознится в изучаемых нами регионах.

Одна из причин отсутствия находок в Финляндии заключается в том, что священные места главным образом используются отдельными людьми, семьями или малыми группами и их местонахождение не разглашается остальным. Такое предположение выдвинул президент Lehto ry, который также отметил, что календарные обряды практикуются в разных местах Финляндии каждый год, поэтому ни одно место не было выбрано постоянным местом проведения обрядов (Krabbe, личное сообщение 2017). Люди могут посещать священные места, но так как не организуются ритуалы, они не оставляют таких легко узнаваемых следов, как более насыщенные посещения в Эстонии. Это же можно сказать и про Эстонию, где основные категории священных мест состоят из личных или семейных и общественных мест (Kaasik 2007: 42), но первые из них сложно локализовать и изучать.

Разные подходы СМИ в отношении священных мест также являются одной из причин, почему подношения в әстонских 
и фринских священных местах так различаются. В то время как финские места обычно чистые и девственные, там мало подношений и они ограничены монетами и пищей, эстонские места активно используются и подношения там весьма отличны по своему характеру. Очевидно, в подношениях преобладают монеты и лоскуты, что популяризируется языческим сообществом. Кроме того, посетители также по-своему интерпретируют то, что они видят на месте или то, о чём они узнали из газетных статей или книг, в результате чего в качестве подношений оставляют очень разнообразные объекты. К ним относятся любые обычные и легко прикрепляемые предметы - отражатели, полиэтиленовые пакеты и резинки для волос. Многочисленными являются также несложные плетёные изделия, такие как Ojo de Dios, упрощённые фригурки ангелов и т.д. Однако такие объекты требуют больше усилий, чем просто монетные подношения, и таким образом отражают более личные аспекты посещения и его цели. В некоторых случаях мы можем видеть прямые отсылки к эзотерическим и магическим практикам, такие как подвески каббалы, ангелы или горные кристаллы, что указывает на переплетение местной языческой и глобальной эзотерической традиций. Многочисленные современные находки, которые содержат отсылки к новым традициям подношений, и ритуальное творчество в священных местах можно рассматривать как способы возродить старые народные верования и создать новые способы коммуникации с этими местами.

Описывая такой процесс, он видится довольно мирно развивающимся, где разного рода верования сплетаются в «неопределённую духовность. Но приветствуются не все подношения. Существует тенденция ограничения современными языческими движениями использования неорганических материалов. В Эстонии было несколько конфрликтных ситуаций, когда языческие организации силой вмешивались, чтобы направить традиции в «правильное» русло. В некоторых местах священные объекты очищаются от неподходящих подношений (полиэтиленовых пакетов и других синтетических материалов). Предположительно, это происходило в нескольких местах в Эстонии, самый известный случай произошёл у священного дерева Илумяэ, о чем сообщалось в местных новостях. Сначала был проведён ритуал по защите участников и у дерева попросили разрешения убрать пакеты и ленты. Потом их срезали с дерева и пе- 
реработали. Таким образом, этот случай является хорошим примером того, как языческое сообщество также берёт на себя ответственность за поведение в священных местах. В Финляндии президент Karhun kansa также сообщил, что некоторые члены организации убирают неорганический материал, такой как пластиковые бутылки и пакеты со священных мест в рамках своих личных ритуалов, но оставляют монеты, так как они могут считаться подношением. Однако это не организовано всей группой, а проводится отдельными участниками (Kiiski, личное сообщение 2017).

Таким образом, мы можем очертить неоднозначную ситуацию, связанную с использованием священных мест в Эстонии и Финляндии. Подсознательно присутствует знание об общей древней истории, похожее мировоззрение и тезис об общей нации. Это подтверждается научными исследованиями народной культуры и народной религии. Однако на практическом уровне мы можем наблюдать очень разные подходы к священным местам и национальной истории/религии. В обеих странах значительную часть ответственности берут на себя современные языческие сообщества. Maavalla Koda форомирует эту ситуацию в последние несколько десятилетий в Эстонии. В итоге, священные места воспринимаются не как символы языческой религии, а как символ эстонской нации и часть её культурного наследия. Такие же тенденции можно увидеть сейчас в Финляндии, где языческие группы стараются балансировать между религиозными и культурными интересами. Персональные священные места остаются за рамками данного исследования и представляют сложность для сравнения. Часть таких мест посещают только отдельные люди или семьи, и причины их посещения очень личные, хотя и связаны чаще всего с исцелением и благодарением.

Популярность священных мест в Эстонии также повлекла за собой использование этих мест другими группами, не только самими язычниками. Они включают сообщества, которые интересуются языческим прошлым, экологичным образом жизни и национальной идентичностью. Такие группы не обязательно должны быть религиозными, чтобы посещать священные места и оставлять подношения. Новые способы использования священных мест могут сочетать элементы разных мировоззрений разных частей света. Таким образом, они оставляют место для ритуального творчества и личных значений. 


\section{Выражение благодарности}

Работа над статьёй осуществлена при поддержке Министерства образования и науки Эстонии (институциональный исследовательский грант IUT 22-5) и Фонда регионального развития EC (Центр компетенции по Эстонским исследованиям CEES TK 145).

\section{Примечание}

1 Айкас также документировала современные подношения в саамских священных местах (Äikäs 2015; Äikäs \& Spangen 2016; Äikäs и др. в печати). Этот обширный материал остался за рамками данного исследования или использовался только как материал для сравнения, так как эти священные места принадлежат к другой культурной традиции и вопросы их современного использования относятся главным образом к другой группе людей, нежели священные места юга.

\section{Литература}

Äikäs, Tiina 2015. From Boulders to Fells - Sacred Places in the Sámi Ritual Landscape. Translated by Sarianna Silvonen. Monographs of the Archaeological Society of Finland 5.

Äikäs, Tiina \& Spangen, Marte 2016. New users and changing traditions (re)defining Sami offering sites. European Journal of Archaeology 19 (1), cc. 95-121.

Äikäs, Tiina \& Fonneland, Trude \& Thomas, Suzie \& Perttola, Wesa \& Kraft, Siv Ellen (in print). "Traces of our ancient religion": Meaningmaking and shamanism at Sámi offering places and at the Isogaisa festival, northern Norway. J. Leskovar (ред.). Archaeological Sites as Space for Modern Spiritual Practice. Cambridge Scholars.

Aleknaitè, Eglè 2017. Neoshamanic interpretations of a local IndoEuropean Religious Tradition. Nova Religio: The Journal of Alternative and Emergent Religions 20/3, cc. 13-35 (DOI: https://doi.org/10.1525/ nr.2017.20.3.13). 
Arola, Iiro 2011. Suomenuskoiset erottautuvat muista uuspakanoista. [Finnish Faith separate from other Pagans.] teologia.fi.https:// www.teologia.fi/54-opinnaytteet/pro-gradut/624-suomenuskoiseterottautuvat-muista-uuspakanoista.

Arukask, Madis 2017. The personal rituals of the Finnic peoples with forest trees (on the basis of two examples). Anthropology \& Archaeology of Eurasia 56/1-2, cc. 167-185 (DOI: https://doi.org/10.1080/10611959. 2017.1352307).

Busch, Nikolai 1937. Studien zur baltischen Vorgeschichte I. Abhandlung der Herder-Gesellschaft und des Herder-Instituts zu Riga 6/1. Rīga.

Fennell, Julie \& Wildman-Hanlon, Laura 2017. The children of converts: Beyond the first generation of contemporary Pagans. Social Compass 64 (2), cc. 288-306.

Heino, Harri 1997. Mihin Suomi tänään uskoo. Helsinki: WSOY.

Hjelm, Titus 2006. Between Satan and Harry Potter: Legitimating Wicca in Finland. Journal of Contemporary Religion 21 (1), cc. 33-48.

Hjelm, Titus 2016. Paganism in Finland. Henrik Bogdan \& Olav Hammer (ред.). Western Esotericism in Scandinavia. Leiden: Brill, cc. 360-366.

Houlbrook, Ceri 2016. Saints, poets, and rubber ducks: crafting the sacred at St Nectan's Glen. Folklore 127 (3), cc. 344-361.

Ivakhiv, Adrian 2005. In Search of Deeper Identities. Neopaganism and "Native Faith" in Contemporary Ukraine. Nova Religio: The Journal of Alternative and Emergent Religions 8/3, cc. 7-38 (DOI: 10.1525/ nr.2005.8.3.7).

Jonuks, Tõnno 2009. "Hiis sites in the research history of Estonian sacred places." Folklore: Electronic Journal of Folklore 42, cc. 23-44.

Jonuks, Tõnno 2013. Der estnische Nationalismus und sein Konzept der prähistorischen Religion: Die Nation als Gestalterin des Religionsbildes. Forschungen zur baltischen Geschichte 8, cc. 145-164.

Jonuks, Tõnno \& Friedenthal, Meelis \& Haak, Arvi 2010. Värtnakeder, talisman või nõiaese - märkidega kiviketas Viljandimaalt Rattama talust. Ü. Tamla (ред.). Ilusad asjad. Tähelepanuväärseid leide Eesti arheoloogiakogudest. Muinasaja teadus 21. Tallinn, Tallinna Ülikooli ajaloo Instituut, cc. 269-286. 
Jonuks, Tõnno (in print). New trends in the study of religion in Estoniacontemplations in the grey zone between religion and science.

Jonuks, Tõnno \& Oras, Ester \& Veldi, Martti (in print). Mix and match, old and new - material remains of religious practices by Estonian pagans. J. Leskovar (ред.) Archaeological Sites as Space for Modern Spiritual Practice. Cambridge Scholars Publishing.

Kaasik, Ahto 2007. Ajaloolised looduslikud pühapaigad - väärtused looduse ja kultuuri piirimail. H. Valk \& A. Kaasik (ред.) Looduslikud pühapaigad. Väärtused ja kaitse. Õpetatud Eesti Seltsi Toimetised 36. Tartu: Tartu Ülikool, Õpetatud Eesti Selts, cc. 23-74.

Koski, Mauno 1967. Itämerensuomalaisten kielten hiisi-sanue. Semanttinen tutkimus, I. [The word hiis in Baltic-Finnic languages. Semantic study I.] Turun yliopiston julkaisuja. Sarja C. Scripta lingua fennica edita. Turun yliopisto.

Koski, Mauno 1970. Itämerensuomalaisten kielten hiisi-sanue. Semanttinen tutkimus, II. [The word hiis in Baltic-Finnic languages. Semantic study II.] Turun yliopiston julkaisuja. Sarja C. Scripta lingua fennica edita. Turun yliopisto.

Kovalainen, R. \& Seppo, S. 2006. Puiden kansa. Helsinki, Maahenki.

Kuningas, Maire 2014. Ravimise ja nõidumise hõbepreesid. Horisont 1, cc. $6-7$.

Laid, E. 1928. Proovikaevamisaruanne "Ülendi lõhmuspuu" juures. Käsikiri TÜ Ajaloo ja arheoloogia instituudi arhiivis.

Laime, Sandis (in print). Offering Cave of the Livs in Latvia - from Sacred Place to Tourist Destination. Prilozi Instituta za arheologiju u Zagrebu.

Melton, J. Gordon 2013. Revisionism in the New Age Movement: The Case of Healing with Crystals. Eileen Parker (ред.). Revisionism and Diversification in New Religious Movements. Farnham, Burlington: Ashgate, cc. 201-211.

Mikita, Valdur 2008. Metsik lingvistika. Grenader.

Mikita, Valdur 2013. Linguistiline mets. Grenader.

Mikita, Valdur 2015. Lindvistika ek metsa see lingvistika. Välgi metsad. 
Olearius, Adam 1669. The voyages and travells of the ambassadors sent by Frederick, Duke of Holstein, to the great Duke of Mucovy and the king of Persia. London.

Potts, Albert M. 1982. The World's Eye. Kentucky: The University Press of Kentucky.

Ringvee, Ringo 2017. Survival strategies of New Religions in a secular consumer society. A case study from Estonia. Nova Religio: The Journal of Alternative and Emergent Religions 20/3, cc. 57-73 (DOI: https://doi. org/10.1525/nr.2017.20.3.57).

Rohtmets, Priit \& Ringvee, Ringo 2013. Religious revival and the political activity of religious communities in Estonia during the process of liberation and the collapse of the Soviet Union 1985-1991. Religion, State and Society 41 (4), cc. 355-393.

Rountree, Kathryn 2014. Neo-paganism, Native Faith and indigenous religion: a case study of Malta within the European context. Social Anthropology 22 (1), cc. 81-100.

Sjöblom, Tom 2000. Contemporary Paganism in Finland. Jeffrey Kaplan (ред.). Beyond the Mainstream. The Emergence of Religious Pluralism in Finland, Estonia, and Russia. Studia Historica 63. Helsinki: SKS, cc. $223-240$.

Tvauri, Andres 1997. Arheoloogiline aruanne Helme ohvriallika puhastustöödest 6. juunil 1997. Tartu: unpublished manuscript.

Vakker, Triin 2012. Rahvusliku religiooni koostamise katsed - Taara usk. Mäetagused 50, cc. 175-198.

Valk, Heiki 2001. Rural cemetries of southern Estonia 1225-1800 AD. CCC papers 3. Visby: Gotland University College \& Centre for Baltic Studies \& Tartu: University of Tartu, Archaeology Centre.

Valk, Heiki 2007a. Looduslikud pühapaigad kui muistised: arheoloogi vaatenurk. [Sacred natural places as archaeological objects.] Looduslikud pühapaigad. Väärtused ja kaitse. H. Valk (ред.). Tartu: Õpetatud Eesti Seltsi Toimetised 36, cc. 135-170.

Valk, Heiki (ред.) 2007b. Looduslikud pühapaigad. Väärtused ja kaitse. [Holy natural places. Values and protection.] Tartu: Õpetatud Eesti Seltsi Toimetised 36. 
Valk, Heiki 2015. Pühast Võhandust, Pühalättest ja ohvrijärvest Otepää lähistel. Ajalooline Ajakiri 3, c. 37.

Västrik, Ergo-Hart 2015. In search of genuine religion. The contemporary Estonian Maausulised movement and nationalist discourse. Kathryn Rountree (ред.). Contemporary Pagan and Native Faith Movements in Europe. Colonialist and Nationalist Impulses. New York-Oxford: Berghahn, cc. 130-153.

\section{Summary}

\section{Contemporary deposits at sacred places: reflections on contemporary Paganism in Estonia and Finland}

\section{Tõnno Jonuks}

Tiina Äikäs

Keywords: contemporary studies, pagan religion, deposits, material culture studies

This paper is based on archaeological fieldwork conducted at sacred places in Estonia and Finland. We study the variation of contemporary assemblages in these countries and interpret them based on the known traditions of contemporary Paganism. Contemporary offerings bear evidence of creative use of past as well as of international influences. It is also emphasised that users of sacred places is broader than the members of Pagan communities but they are often left asides in studies. The attitudes of general public become visible particularly during the material culture studies when examining all deposits comprehensively. 


\section{МИССИЯ ВЫПОЛНИМА Перспективы изучения фольклора}

http://www.folklore.ee/rl/pubte/ee/sator/sator19/

ISSN 1736-0323

ISBN 978-9949-586-60-8

DOI: $10.7592 /$ Sator.2018.19

Тарту 2018

Редакторы-составители выпуска:

Маре Кыйва \& Татьяна Володина

Редактор серии: Маре Кыйва

Фото: Яак Кикас, 2018 «Осень в Тарту»

Оформление обложки: Лииса Весик

Верстка \& HTML: Диана Кахре

Печатное издание: МИССИЯ ВЫПОЛНИМА:

Перспективы изучения фольклора. SATOR 19. Тарту 2018

Публикация книги осуществлена совместно Эстонским литературным музеем и Центром исследований белорусской культуры, языка и лит ерат уры Националь ной акад емии наук Б еларус и, п ри поддержке Министерства образования и науки Эстонии (IUT 22-5), Фонда регионального развития ЕС (ТK 145, Центр компетенции по Эстонским исследованиям); при поддержке проекта, финансируемого Министерством иностранных дел Эстонии из бюджета по сотрудничеству и развитию, Эстонской Академией Наук и Национальной академии наук Беларуси.

Оформление электронного издания осуществлено при поддержке проекта ЕККМ14-344 “Расширение областей применения и представление эстонского языка, культуры и фольклора в электронных информационных средствах".

() Эстонский литературный музей

(c) Авторы

(с) Яак Кикас 